Abstracta Iranica Abstracta Iranica

Revue bibliographique pour le domaine irano-aryen

Volume 25 | 2004

Comptes rendus des publications de 2002

«The Sasanian King Khusrau II (AD 590/1-628) and Anāhitā ». Nāme-ye Irān-e Bāstān 2/1, 2002 (paru en 2003), pp. 23-40, pl. 1-3.

\title{
Rika Gyselen
}

\section{(2) OpenEdition}

1 Journals

Édition électronique

URL : http://journals.openedition.org/abstractairanica/4366

DOI : 10.4000/abstractairanica.4366

ISSN : 1961-960X

\section{Éditeur :}

CNRS (UMR 7528 Mondes iraniens et indiens), Éditions de l'IFRI

\section{Édition imprimée}

Date de publication : 15 mai 2004

ISSN : 0240-8910

Référence électronique

Rika Gyselen, « «The Sasanian King Khusrau II (AD 590/1-628) and Anāhitā ». Nāme-ye Irān-e Bāstān 2/1, 2002 (paru en 2003), pp. 23-40, pl. 1-3. », Abstracta Iranica [En ligne], Volume 25 | 2004, document 106, mis en ligne le 15 mars 2006, consulté le 25 septembre 2020. URL : http://

journals.openedition.org/abstractairanica/4366 ; DOI : https://doi.org/10.4000/abstractairanica.4366

Ce document a été généré automatiquement le 25 septembre 2020.

Tous droits réservés 


\title{
« The Sasanian King Khusrau II (AD 590/1-628) and Anāhitā ». Nāme-ye Irān-e Bāstān 2/1, 2002 (paru en 2003), pp. 23-40, pl. 1-3.
}

\author{
Rika Gyselen
}

\begin{abstract}
À côté de ses émissions monétaires courantes, Khosro II a aussi émis un type exceptionnel caractérisé par des légendes spécifiques et surtout par un revers qui porte le buste de face d'un personnage dont la tête est entourée de flammes ou de rayons. Cet article traitant de l'identification de ce personnage et essayant de mettre en rapport ces émissions (années de règne 21 (ou 23), 26, 27, 28, 36 et 37) avec des victoires sassanides sur les Byzantins est accompagné d'un catalogue de toutes les monnaies de ce type. Un autre article de conception quelque peu différente a été consacré à ce même sujet (voir R. Gyselen, «Un dieu nimbé de flammes d'époque sassanide », Iranica Antiqua, vol. XXXV, pp.291-314). Les deux articles diffèrent sur l'interprétation iconographique et épigraphique de ce type monétaire exceptionnel, mais proposent tous les deux de mettre sa création en rapport avec les relations byzantino-sassanides, hypothèse qui me semble à présent de plus en plus improbable.
\end{abstract}

\section{INDEX}

Thèmes : 3.2.3. Séleucides, Parthes et Sassanides 
AUTEURS

RIKA GYSELEN

CNRS - Paris 